\title{
Democratic Hopes in the Polycentric City
}

Loren A. King

Brown University

\begin{abstract}
The polycentric model of municipal governance suggests that multiple jurisdictions may approximate an efficient market for local public services: citizens move to jurisdictions offering services they value at tax rates they are willing and able to pay. The model is appealing to political theorists for its emphasis on free association and responsive governance, but problematic insofar as institutions prescribed by the model permit exclusionary practices and objectionable inequalities. I argue for a revised conception of polycentricity: efficient spatial patterns of boundaries and services are acceptable only if they are consistent with (inter alia) fair opportunities for both mobility and loyalty to place. This suggests a vision of the polycentric city in which fairness and contestation are as important as freedom and efficiency.
\end{abstract}

$\mathbf{T}_{1}$ he polycentric model of municipal governance suggests that multiple jurisdictions may approximate an efficient market for a range of public services. As a normative ideal, the model should appeal to liberals and libertarians for its emphasis on freedoms of choice and association: citizens are free to move to jurisdictions that provide the services they value, at the price they are willing and able to pay. When preferences, service quality, tax rates, and budget constraints change, citizens are free to move to more suitable jurisdictions. The model should also be attractive to communitarian and republican democrats: citizens sort themselves according to shared values and preferences, and political authority is vested in relatively small and independent jurisdictions, allowing citizens to have real influence over decisions that directly affect their lives. And of course few theorists would deny the appeal of efficient and responsive government.

But any ideal of governance that appeals to both libertarians and republicans, liberals and communitarians, perhaps ought to give us pause, and indeed a tension is evident between the liberal and democratic commitments of this ideal: the polycentric approach threatens to sustain exclusionary political practices and dramatic inequalities of resources and opportunities, both of which undermine an attractive account of fairness central to much recent liberal political thought.

My aim here is to provide a normative analysis of the polycentric approach to municipal governance. I offer a spatial interpretation of the account of fairness suggested by Rawls (1999 and 2001) and elaborated as an expressly democratic ideal by Cohen (2003). I then argue that political theorists concerned with effi- 
ciency, freedom, and fairness may be able to reconcile some of their democratic hopes with the market metaphor that sustains the polycentric ideal. But this reconciliation requires that we understand polycentricity not simply in terms of efficiency, but primarily in terms of fairness with respect to both spatial mobility and loyalty to place. This in turn suggests a vision of the polycentric city in which fairness and public contestation are as important as freedom and efficiency.

\section{Justice as Fairness}

By "fairness" I have in mind political principles and associated institutions that seek to balance liberty with a commitment to some standard of equality. ${ }^{1}$ For my purposes here, I adopt the account of justice as fairness advanced by Rawls (1999 and 2001) that requires inequalities of wealth and expectations to be consistent with equal basic liberties. Furthermore, inequalities must be part of a system of social cooperation in which similarly capable and motivated citizens face similar life prospects (fair equality of opportunity). Given equal basic liberties and fair equality of opportunity, inequalities must work to the greatest benefit of citizens occupying the least advantaged position in society (the difference principle).

Justice as fairness allows that equal liberties may have unequal worth to citizens as a function of differing abilities, inclinations, and especially differences in wealth and education. But such differences in the worth of liberty are permissible only if they better protect other basic liberties and can be shown to do so in ways that citizens - especially those whose liberties are of lesser worthcan accept as reasonable (see Rawls 1999, 171-227 esp. 178-79, 187-89, and 203). The idea is that, together, fair equality of opportunity and the difference principle ensure that the worth of liberty is maximized for those facing the least attractive prospects in society.

Rawls offers a famously evocative argument for why we would pay so much attention to the plight of those facing the least attractive prospects in society: such attention is rational for parties who must agree to binding principles of justice without appealing to specific information about their talents, beliefs, aspirations, wealth, and social positions. Rawls asks us to imagine these parties as actually ignorant of their particular features, instead knowing only that their agreement on mutually binding principles is final, and that the basic structure of society associated with any set of principles will almost certainly result in some persons having less attractive life prospects than others. Under such conditions, rational parties would, Rawls argues, try to ensure not only extensive personal liberties for all, but also an adequate minimum position: they would want to guarantee that the least attractive positions in society are nonetheless such that occupants

\footnotetext{
${ }^{1}$ Much work in political philosophy has examined the distributional demands of such balancing efforts: does fairness permit any inequalities? what must be equalized, or maximized, and for whom, to achieve a fair distribution: income? wealth? happiness? respect? employment opportunities? life chances more generally? political influence? freedom from domination? For a sense of the nuances of these debates see Cohen (2000), Dworkin (2000), Sen (1992), van Parijs (1991), and Varian (1975); for a critical assessment of much of this debate, see Anderson (1999) and Scheffler (2003).
} 
can exercise their liberties and possess sufficient means to live a satisfying life. After all, absent specific information about our wealth, talents, and social positions, we cannot estimate the likelihood that we in fact occupy undesirable positions.

Why should we think about justice in this way, divorced from specific knowledge of our talents, aspirations, and social positions? Because, following a philosophical tradition grounded in Kant, we tend to associate personal responsibility with our ability to make informed, uncoerced, reasoned choices about our actions, and more generally about the course of our lives. Central to modern liberal political thought is the idea that, however much our particular beliefs and aspirations are shaped by formative traditions and associations, our lives are, ultimately, best lived according to our own judgments.

To be sure, our judgments may be intimately related to-indeed, in some cases overwhelmingly determined by - our class position, ethnic history, cultural heritage, and religious beliefs. In a diverse and unequal society, the question of moral responsibility will rarely be resolved by simple appeals to the relation between choices and their consequences. Rather, under such conditions we may expect rational parties to disagree about the consequences for which persons may reasonably be held responsible, and the degree to which particular motives and expectations are bound up with formative traditions that deserve our respect.

But even given such nuances, it is difficult to see how anyone could meaningfully be thought to deserve their inherited traits, or the wealth, compassion, and competence of their parents, or especially the places where they are born and raised, and that come to have significance in their lives. As Rawls $(1999,64)$ suggests, even our talents, aspirations, and eventual positions in society are at least to some extent morally arbitrary insofar as they can be traced not simply to our own efforts, but also in part to unchosen features of our formative environments. It is this intuition, paired with a commitment to the idea of citizens as free and equal moral agents, that moves us beyond concerns for liberty and efficiency to considerations of fairness: Rawls provides criteria for selecting among efficient distributions of resources and opportunities that are each compatible with liberty, but some of which offend reasonable intuitions about luck, entitlements, and our standing as citizens. ${ }^{2}$

Consider, for instance, the plight of a citizen born into an urban neighborhood plagued by poverty, violence, and poor services. Our citizen may enjoy a range of liberties, protected by a scheme of rights and duties. Suppose that this scheme results in a spatial distribution of wealth and employment opportunities more efficient than distributions associated with alternative schemes. Demands for liberty and efficiency are thus satisfied. But our unlucky citizen will find that, through no fault of her own, her liberties have far less worth than those enjoyed by citi-

\footnotetext{
${ }^{2}$ Rawls (2001, 72-79) is careful to distinguish legitimate expectations and associated entitlements from accounts of moral desert: the latter are grounded in comprehensive moral, religious, or philosophical doctrines, whereas the former emerge from political conceptions of justice that may be consonant with some prevalent understandings of moral desert, but do not depend upon controversial claims about religious truth, moral worth, or the nature of a good life.
} 
zens lucky enough to be born into affluent neighborhoods with low crime rates and good schools. Yet such divergent prospects are not unavoidable facts of nature. Rather, the prevailing scheme of rights and duties allows-indeed, sustains - inequalities that trace at least in part to arbitrary differences in formative circumstances. Various schemes of rights and duties may satisfy reasonable demands for liberty and efficiency, yet differ considerably in their sensitivity to such unchosen factors. Justice as fairness offers a way to take seriously the intuition that our standing as citizens ought not to be overwhelmingly determined by unchosen contingencies, while nonetheless preserving incentives for employment and location decisions that are grounded in liberty, foster economic innovation and growth, and tend toward efficiency.

The Rawlsian framework achieves a principled balance between compensating for unchosen burdens, on the one hand, and evaluating structures of power that sustain distributive patterns, on the other. ${ }^{3}$ This balance reflects the democratic character of Rawls's account: the point is not simply that some burdens are unchosen and hence undeserved, but that burdens and benefits are importantly influenced by prevailing institutions; that these institutions ought to reflect an ideal of citizens as free and equal partners in social cooperation; and that this ideal suggests the moral irrelevance, to citizenship, of certain unchosen features of persons. Justice does not require strict insensitivity to unchosen features, such that, for instance, distributions are both efficient and free of envy, in the sense that no party would prefer what another party has (Varian 1974, 1975; Dworkin 2000, chapter 2). Rather, distributions should emerge from a basic structure that reflects and sustains the equal standing of free citizens. Equal standing as citizens requires that we enjoy the social bases of self-respect and that political liberties be guaranteed their fair value (Rawls 2001, 58-61 and 148-52). Self-respect is fundamental to exercising our liberties in pursuit of a satisfying life, and vital to such respect is some measure of respect by others, demonstrated "not simply by recognizing me as an equal in some way, or attributing to me some equal rights regardless of the content of those rights, but as an equal with respect to making the final authoritative judgements about collective affairs" (Cohen 2003, 109).

The emphasis on equal terms of citizenship in defining fairness (rather than, say, the absence of envy and a broader equality of resources) matters to the following analysis: when we assess the polycentric approach in light of considerations of fairness thus understood, we arrive, I will argue, at a more democratic conception of polycentricity, according to which tensions between freedom, fairness, and local autonomy are less pronounced. And so while justice as fairness has been applied to the spatial forms of urban areas before, most notably in early work by Harvey (1973, 96-118), subsequent applications (e.g., McConnell 1995) tend to apply the principles of justice-particularly the

\footnotetext{
${ }^{3}$ The importance of such a balance is suggested by Anderson (1999, esp. 314); see also Scheffler (2003).
} 
difference principle - as distributional constraints imposed on democratic politics. My aim here is to treat these principles as themselves a democratic expression of liberal justice.

We might still fault Rawls for permitting incentives that conflict with his own difference principle: some citizens with scarce talents may require sufficient incentive to deploy those talents (a gift for applied mathematics, perhaps) instead of others they may prefer to exercise (modest skill at poetry, say). And the reservation wage they settle on for using their more socially beneficial talents may be considerably higher than average. In such cases, the least advantaged would be worse off under a more equitable distribution of resources not by virtue of brute facts of allocative and productive efficiency, but rather because of the preferences of these talented individuals. Cohen (2000, 117-47 esp. 122-28) argues that if, as Rawls says, citizens freely affirm shared principles of justice in a just society, then the society in question is not just, because these talented individuals are not affirming the difference principle. Carens (1986) points out, for instance, that the talented might instead be motivated by a duty to contribute to the common good according to their abilities, thus generating a more equitable distribution. Of course some, perhaps many, apparent incentive inequalities may in fact reflect vagaries of labor markets and educational opportunities, as Cohen (2001,374-75) suggests. Yet even given this important caveat, the "incentive inequality" objection clarifies an important point: our sense of what we may reasonably ask of others as we pursue a satisfying life, and what others may reasonably demand of us in their similar pursuits, is shaped by a "social ethos."

But as Joshua Cohen (2001) argues, the motivations behind different classes of incentive inequalities are essential to our considerations about justice, and some problematic motivations - racist attitudes, for instance, or an obsessive concern with relative advantage - will be discouraged by other features of a just basic structure, specifically the sorts of institutions that embody the priority of equal basic liberties, a fair value of political liberties, and fair equality of opportunity. Gerald Cohen's (2000) criticism makes clear the importance of a social ethos in shaping preferences and expectations, but he does not acknowledge the degree to which just institutions can transform the prevailing ethos, discouraging odious preferences and inclinations, while simultaneously protecting reasonable aspirations and associated life choices. ${ }^{4}$

The Rawlsian account of justice as fairness provides, then, a powerful and persuasive normative framework for evaluating political institutions and outcomes. Given this account of fairness, I turn now to an evaluation of the polycentric approach to municipal governance, which is arguably motivated by concerns for liberty, efficiency, and incentives for innovation in the provision of public services.

\footnotetext{
${ }^{4}$ On these ideas consider also van Parijs (2003, 230-31), and especially Daniels (2003, esp.
} 267-70). 


\section{The Polycentric Approach}

In a seminal article, Tiebout (1956) provides the basis for a powerful argument in favor of granting political authority over local public service provision to several jurisdictions, rather than opting for a more centralized system of governance and administration. Tiebout argues that, by offering bundles of services at differing tax rates, several jurisdictions could approximate an efficient market for public services by allowing individuals to sort themselves in space according to their preferences, moving to jurisdictions that provide the services they most value, at tax rates they are willing to pay. For most local public services there will be increasing returns to scale up to a critical membership level, beyond which increased numbers of recipients will diminish the quality of services for a given tax rate. Thus an equilibrium should emerge, with more efficient means of providing particular bundles of public services being limited to an ideal membership level and associated tax rate.

Building upon Tiebout's work, Ostrom, Tiebout, and Warren (1961), Bish (1971), Ostrom (1972), and Schneider (1989) have developed a polycentric approach to municipal governance, arguing that a multiplicity of relatively independent jurisdictions in a region is not necessarily pathological. The desirability of such political fragmentation - specifically, the desirability of competition or coordination among particular levels of government-needs to be assessed in terms of the nature and scope of the specific public services being provided.

To be sure, some vital services (such as pollution control and investigation of criminal activities that span several jurisdictions) may require a strong central agency, either to provide the service in question (i.e., regulation and enforcement of environmental standards), or to coordinate the efforts of local agencies (i.e., collecting, standardizing, and disseminating information on industrial emissions and associated risks, or the financial transactions of suspected criminals). But competing governments may be able to provide other services (such as schools, recreational areas, zoning regulations, and policing) with greater sensitivity to diverse needs and preferences.

Both Tiebout's original model and the polycentric approach have been reformulated and extended in constructive ways. For example, recent theoretical work on the Tiebout model has examined the performance of alternative social choice procedures in sorting citizens by preferences (Kollman, Miller, and Page 1997). But controversy has ensued over the explanatory power of Tiebout-style models and, more critically, the desirability of associated policy prescriptions.

Tiebout's model made strong informational demands: for spatial sorting to result in efficient service provision, citizens must be sufficiently informed about the quality and costs of services in competing jurisdictions. Lowery and Lyons (1989) argue that this condition may be difficult to satisfy, although subsequent research by Percy and Hawkins (1992) has qualified the generality of these findings. Indeed, Ostrom (1977) suggests that citizens may sometimes be able to make reasonable estimates of service quality, especially near their homes, and 
Teske et al. (1993) further suggest that a relatively small number of informed citizen-consumers may sustain competitive outcomes in such settings.

We should, however, be concerned that informed citizens may be difficult to identify, and so any first movers might generate perverse cascades: Scharfstein and Stein (1990) and Banerjee (1992) argue that, in markets with imperfect information and "first mover" advantages, some otherwise-prudent actors may discount private information in favor of public signals generated by first movers. Furthermore, there is an incentive for some providers to misrepresent the quality of their services so as to make themselves indistinguishable from higher-quality providers. Anticipating this, consumers may discount information gained from any providers, thus undervaluing higher-quality services (Akerloff 1970). If these services tend to be discounted too sharply, and if entry costs are high for new providers, then higher-quality services may be underprovided. It seems to follow that, in the absence of timely and reliable sources of information available to consumers, markets for public services are unlikely to be competitive.

Tiebout's analysis also assumed a high degree of mobility, a condition that is only rarely met in reality, and even then only for those with sufficient wealth and few, if any, vested interests in their current locations. Although some businesses may accept the costs of relocation, given expectations about market demand and regulatory environments, the assumption seems unrealistic for individuals and families. Financing a new home is an expensive and time-consuming process, and there are significant personal costs involved in leaving behind friends and familiar habits and institutions, and forging new ties elsewhere. Families may well choose to move elsewhere for safer streets and better schools if their present circumstances are dire enough, and their income allows them to move (on this consider the findings of Hoyt and Rosenthal 1997). But we should not expect repeated moves whenever tax rates and service quality fluctuate.

Following an influential analysis by Hirschman (1970), Lyons and Lowery (1986) have pointed out that political activity is an obvious alternative to exit when citizens are dissatisfied with current services in their jurisdiction. Hirschman suggests that loyalty to particular organizations - or in this case, particular places with distinct bundles of public services, community associations, and political organizations - is likely to emerge (1) when voice requires considerable effort but is, with some creativity, likely to exert a positive influence, and (2) where exit is feasible but threatens significant costs (1970, chapter 7, esp. 78-82 and 98-105). Given that effective opportunities for exit tend to be dramatically constrained for less-affluent citizens, especially in urban areas with poor services and concentrated poverty, we might expect loyalty to emerge in these neighborhoods as residents voice pressing concerns and seek to bring about much-needed change through creative forms of protest and community organization.

But voice is unlikely to be effective in just these settings: given limited household income and assets, threats of exit are not credible, and even if they were, local officials face rigid constraints in financing public services, regardless of the 
intensity and creativity of residents' efforts to foster change. Furthermore, the cause of these constraints on citizens and officials is arguably the very combination of spatial sorting and local control that is central to the polycentric model. ${ }^{5}$

\section{Mobility against Injustice}

Much of the popular appeal of the polycentric approach lies in the hope that mobility and jurisdictional autonomy will together force governments to be more responsive to citizens: the threat of exit ensures accountability and fosters innovation in the face of changing demands. But some citizens are burdened by poverty and poor services, and these citizens cannot opt to leave their jurisdiction, arguably through no fault of their own, and indeed quite possibly due in part to past and enduring injustice. ${ }^{6}$

Theorists of a liberal persuasion may argue that, given these realities, we should intervene to enhance mobility for just these citizens, using state and federal tax revenues to support home rental and school voucher programs, education incentives, job training programs, and aggressive enforcement of existing statutes against discrimination by employers, banks, and realtors. By making exit a feasible option for all citizens we ensure that no one is forced to endure inept or unresponsive government.

Fiss (2003) suggests such a policy, focusing on the lamentable situation endured by many residents of central city neighborhoods in the United States. In contrast to community-oriented initiatives that seek to revitalize distressed urban neighborhoods, Fiss's solution extends the intuition behind the 1976 U.S. Supreme Court decision in Hills v. Gautreaux. This ruling upheld a lower court judgement, in 1969, that both the Chicago Housing Authority and the federal Department of Housing and Urban Development bore responsibility for racial segregation in their location decisions for public housing within the city of Chicago. The resulting Gautreaux program allowed residents of, and approved applicants for, public housing to relocate throughout the Chicago metropolitan area (see Rubinowitz and Rosenbaum 2000).

But Fiss's proposal is not limited to current residents of public housing in U.S. central cities. Rather, his is a more ambitious effort to break up concentrated poverty and social isolation of distressed neighborhoods throughout U.S. metropolitan areas, by using government programs and subsidies to create incentives for relocation by current residents to safer middle-class and racially integrated neighborhoods closer to employment opportunities and good schools. The physical spaces of distressed areas can then be left to private developers, to be transformed as markets dictate.

\footnotetext{
${ }^{5}$ On this point see Hill (1974). But see also Ostrom (1983) and Morgan and Mareschal (1999).

${ }^{6}$ I think "justice as fairness" provides sufficient reason to be troubled by these burdens, but Shklar (1990) offers further support for such concern in an illuminating analysis of when misfortune may be, or become, an injustice.
} 
The Gautreaux program is not, of course, the only (or even the most prominent) attempt to solve the seemingly intractable problem of the urban ghetto. Federal and state welfare reform, and tougher police tactics in central cities, are prominent recent initiatives, and in the long term they might have the desired consequence of breaking the self-perpetuating cycle of poverty, broken families, and welfare dependence within distressed central city neighborhoods. But the more immediate consequence of such measures has arguably been to exacerbate the painful results of a vicious cycle of poverty, racial discrimination, and fractured communities. Welfare reform has been justified to voters as a way to increase the efficiency of government by eliminating ineffective programs that have always been prone to exploitation; and certainly the trend toward tougher police tactics in cities such as New York has been politically popular, in that officials can appeal to safer city streets for affluent (and predominantly white) urban residents and suburban or out-of-town visitors. But these measures risk reifying the treatment of symptoms - petty crime, vandalism, drug use, welfare dependence - at the expense of careful attention to the underlying pathologies that generate and sustain these symptoms.

A more promising set of policies have involved efforts to intervene in the cycle of poverty, unemployment, welfare dependence, parental neglect, and general culture of despair and violence characteristic of the ghetto. The cycle begins early in a child's life growing up in the ghetto, and efforts such as Head Start have tried to intervene early, to provide children with better guidance than they might otherwise receive in broken homes and fractured neighborhoods, arguably with some modest degree of success (Currie and Thomas 1995; Currie 2001). Similar efforts have attempted to use public school curricula or neighborhood youth organizations to impart upon children the values of personal responsibility, self-respect, care for others, and a love of learning. But as Fiss notes, these programs can only reach so far into the lives of children and adolescents: eventually the child or teen must return home from the school or community center, and if their home life or neighborhood is grossly inadequate, then these programs can have little effect there.

And then there are efforts to bring investment and employment back into the ghetto, along with improved access to credit and job training programs, and reform of public schools and other services. Community-based initiatives such as Chicago's South Shore Bank (Taub 1988), Boston's Dudley Street Neighborhood Initiative (Medoff and Sklar 1994), FINCA's and Accion's microcredit efforts in several U.S. cities, and a variety of faith-based community initiatives seem to have some positive social and economic impact, however modest. These community-oriented initiatives help citizens transform their neighborhoods in the face of marginalization by existing economic and political institutions.

Such initiatives - especially those offering financial services and training programs - do not, however, seem to be especially beneficial to the poorest and most troubled members of the communities they serve (Bates 1995; and Servon and Bates 1998), and Fiss is surely correct to suggest that these reform efforts must 
fight an uphill battle against the many attitudes and incentives, both within and outside of distressed communities, that sustain poverty and isolation. Indeed, when efforts such as community banks and job training programs are successful, they may well have the perverse consequence of robbing communities of potential role models. These programs tend to select for those residents who already possess sufficient motivation and some level of education and training. When these participants have been taught specific skills, given the necessary resources, and encouraged to succeed in, say, a business venture or community development project, they may eventually choose to leave their current locations, in search of more personally satisfying and financially lucrative opportunities elsewhere.

But the departure of talented and motivated citizens from distressed areas may not be a bad thing, an observation that leads to Fiss's proposal: generate opportunities for people to escape poverty and poor services, and to settle instead in communities with good public services, and close to a variety of employment opportunities. Such a project will be long and expensive, to be sure. And it will involve more than simply rent vouchers and reform of some zoning ordinances in relatively affluent residential neighborhoods: also required are the vigorous enforcement of antidiscrimination laws in realty and home financing, as well as supplementary education and job training programs, so that new residents can take advantage of available opportunities.

Fiss is drawing on the intuition that, given the chance, many residents of poor and isolated urban ghettos would choose to find a home and job somewhere else, if only their mobility were not severely restricted. After all, as with any neighborhood, most ghetto residents are honest citizens who would prefer a secure job located in or near a safe neighborhood with reliable public services and good schools: like so many other citizens, they want the chance to build wealth for themselves and their families. ${ }^{7}$ A critical factor preventing these citizens from achieving their desired ends is the spatial structure of contemporary urban economies, and the exclusionary politics that prevents job seekers in the central city from locating near, or even easily commuting to and from, jobs in outlying areas. Given these conditions (and given historical legacies of oppression and discrimination they arguably reflect), Fiss suggests that, as a point of justice, we owe citizens of these neighborhoods the chance to leave and to find safe residence and gainful employment elsewhere. ${ }^{8}$

I share Fiss's sense that there are good reasons to challenge the motives behind — and the incentives that sustain — cultural, class, and racial homogeneity in U.S. metropolitan areas, even if the costs of such a challenge are formidable. Indeed, the use of tax revenues to support such a sweeping venture seems eminently justifiable. After all, such uses of public funds and state powers are not

\footnotetext{
${ }^{7}$ Relevant here are distressing findings about the extent and persistence of racial inequalities in personal and household assets; see Oliver and Shapiro (1995) and Conley (1999).

${ }^{8}$ Could we generalize this line of argument beyond troubled neighborhoods in U.S. cities? On the one hand, the "mobility" metaphor seems to resonate with particular force in the United States: "the
} 
simply the redistributive efforts criticized by libertarians such as Nozick (1974), and viewed with scepticism by scholars such as Epstein (1985). Rather, redistributive efforts in this case arguably represent an effort to correct past injustices and, in so doing, to establish fair terms of political organization and economic activity that reasonable citizens would, upon informed reflection, accept as consonant with justice.

Nozick seems to allow for redistribution to rectify past injustice (1974, 152-53). Fairness, however, is not an acceptable rationale, because sustaining a fair distribution inevitably involves restricting the liberty of some to use their property without undue interference by others. Liberty, Nozick famously argued, disrupts such patterns (163-64). But the force of Rawls's account of justice as fairness is that it grounds our considerations of justice not in foundational Lockean claims about self-ownership, acquisition, and entitlement, but in the reasonable expectations of rational parties, who seek terms of social cooperation that embody the idea of citizens as free and equal persons with distinct values and aspirations. Rawls's approach is thus political in a sense that Nozick's is not.

To see why, consider that Rawls asks us what sorts of reasons we ought to find persuasive in accepting binding principles of justice, given that we must treat one another as free and equal. Nozick's "historical entitlement" approach, in contrast, justifies distributions according to whether they arise from acquisition by, and exchange among, free persons who ultimately own their bodies and their labor power. But this approach trades off freedom against equality in such a way that, over time, the liberties of some will have dramatically less worth than those of others, owing in large part to the choices of past generations, and also to the luck of those positioned favorably in the initial distribution of natural resources. Suppose instead that we imagine rational agents under conditions of moderate scarcity, coming together to decide on binding principles of social cooperation for themselves and subsequent generations. They will surely anticipate that, under the principles Nozick endorses, liberties will be of unequal worth for some, perhaps many citizens at some point in the future, and that this outcome is likely to obtain for a wide range of possible initial distributions of talents and resources. If these parties were uncertain about the likelihood of ending up in a favorable region of the expected distribution - indeed, so uncertain that they had no plausible basis for estimating such likelihoods - then why would they agree to

frontier" has always held economic, political, and imaginative importance, and in popular culture we find an enduring theme of personal growth through travel and settlement in new places, paired with a deep ambivalence about urban life. Given this history, it may be that market-based mobility policies are more relevant to U.S. metropolitan areas than, say, comparable regions in Canada or Europe with rather different political, economic, geographical, and cultural histories. But on the other hand, the idea that undesirable location may be an unchosen burden, and the suspicion that enhanced mobility might foster efficiency and accountability, both seem broadly applicable, especially in regions where wealth, opportunities, and quality of government vary considerably. Indeed, ongoing arguments about international distributive justice, and immigration laws and the treatment of foreign workers, suggest the broader relevance of location and mobility to questions of justice. 
Nozick's principles without some qualifications to mitigate against situations where their liberties have little worth, regardless of their choices? If we accept the idea that citizens are free and equal moral persons with the capacity to act according to their own values and judgements, and also that legitimate expectations and entitlements are ultimately grounded in autonomous choice by such agents, then this thought experiment is how we ought to evaluate the acceptability of principles of justice. Nozick takes seriously the idea that citizens are autonomous moral agents, but not the intuition that the basic structure of society should be consonant with their reasonable judgements about responsibility, entitlement, and the equal standing of citizens.

Fiss's proposed redistributive efforts ought to be understood in this Rawlsian way because prevalent patterns of spatial exclusion in American metropolitan regions represent an interference with the fair worth of liberty and fair equality of life chances; as such, these patterns offend the ideal of citizens as free and equal. By virtue of the choices of others, liberties have little value for some citizens in particular locations, and it cannot plausibly be argued that these unequal life chances, stemming from poverty and constrained mobility, are such that they are not only Pareto-efficient, but also maximize the worth of liberty for the least advantaged, and thus ought to be accepted as reasonable by all citizens, including those facing diminished life prospects. Or at least no such argument is generally made, beyond the suggestion that efficiency is beneficial to all. We need not dispute this limited claim, of course; but it does not follow that alternative institutional arrangements and resultant spatial distributions of resources and opportunities cannot remain at (or sufficiently near) the Pareto frontier, and yet also enhance the prospects of the least advantaged.

\section{Is Mobility Enough?}

Insofar as the Gautreaux program has been successful, it has involved a process of racial integration and class assimilation. Several of the former ghetto residents who chose to relocate to suburban areas have raised themselves and their families into the American middle-class. They have found employment, learned new skills, made new friends, and provided for their children, who can now attend good schools in safe neighborhoods. Rubinowitz and Rosenbaum (2000) found that although many Gautreaux participants experienced setbacks and discouraging encounters after moving to more affluent neighborhoods, they were nonetheless relatively successful in integrating into these (predominantly white and middle-class) suburban communities. Racial discrimination by established residents (in the form of outright harassment or more subtle forms of exclusion from neighborhood activities) tended to decrease over time.

Of course, as Fiss and Rubinowitz and Rosenbaum note, the Gautreaux program was rather modest in scope, and when relocation involved placement in suburban neighborhoods rather than other city locations, generally only a few 
(and almost always black) families at a time would be placed, and in neighborhoods whose residents were predominantly white. Even if more ambitious integration efforts are attempted along the lines Fiss proposes, and even if these more ambitious efforts result in successful integration across racial lines, there are questions of whether the resulting class homogeneity is desirable, and what is to be done when citizens are unable or unwilling to assimilate in this way.

\section{Exclusionary Motivations}

Recent work by Oliver (1999) suggests that local political participation within metropolitan jurisdictions diminishes with greater affluence and class homogeneity, suggesting that, by encouraging citizens to sort themselves according to preferences into economically homogeneous and relatively independent political jurisdictions, we diminish the likelihood of fruitful political cooperation across these spatial boundaries and associated class differences. Furthermore, when affluent urban and suburban citizens do participate in local affairs it is often in divisive zoning disputes or "not in my backyard" activism against developments that might threaten property values. Relatively affluent homeowners often wish to prevent construction of affordable housing options in their neighborhoods, and stifling opposition can arise to proposed bus routes to better serve central city workers commuting to jobs in or near affluent suburban neighborhoods. Considerable opposition may arise even to uses of local and state tax revenues that promise clear benefits and reasonable costs, such as drug treatment programs, subsidized prenatal care and parent training, and job training initiatives.

For the political theorist who is committed on the one hand to a fair equality of life chances, and on the other hand to an inclusive public sphere in which bearers of diverse values, interests, and expressive styles can find a hearing, the problem is not simply that mobility initiatives seem to allow political indifference, but that they are associated with outright exclusionary politics aimed at preserving a spatial status quo with respect to class - and generally also racial and cultural - homogeneity. Enhanced mobility might succeed in fostering racial integration, but it still allows affluent citizens to sequester themselves from others and to think of politics largely in terms of reinforcing the spatial boundaries of class-differentiated neighborhoods.

This last concern deserves particular emphasis: the worry for democratic theory raised by Oliver's findings is not merely that political engagement and participation may decline with economic homogeneity. Rather, the concern is that the political imagination of affluent citizens may be constrained in ways harmful to democratic aspirations: if there are few visceral and enduring experiences of public life beyond carefully policed urban and suburban enclaves, then there is unlikely to be much willingness on the part of affluent citizens to imagine citizenship as requiring more than occasional fleeting acts of engagement across a variety of personal differences and spatial scales. 


\section{Exclusion, Fairness, and Loyalty to Place}

Mobility initiatives seem to allow for exclusionary motivations and activities among the affluent. They do, however, promise to help sufficiently motivated citizens become more affluent, integrating into more desirable neighborhoods than those they leave behind. Some might conclude that this is the best that can be done for those citizens who, by brute bad luck, were born into a ghetto and never gained the necessary skills and motivation to enable them to leave, even when exit is subsidized.

Some citizens may, however, choose to remain in distressed neighborhoods for reasons that other citizens of a free and fair polity have no good cause to dispute. Increasingly, liberals have come to accept the normative importance of community membership to the meaningful exercise of personal liberty. But communities - especially the characteristic institutions of formative communities: schools, churches, neighborhood associations, even parks and cafés - are almost always bound to specific locations, particular places. Such places come to have significance as sites of rituals, habits, and encounters that eventually define who we take ourselves to be, as persons and citizens.

Loyalty to particular places may, of course, importantly reflect assessments of tangible personal benefits (for individuals and families), and strategic considerations (especially for firms, given transportation costs and the spatial distribution of consumers and competitors). ${ }^{9}$ In all likelihood, however, free citizens will also develop loyalties to particular places as sites of formative associations and practices. Such valuations of places are difficult to weigh against more tangible costs and benefits associated with specific locations, certainly. But if we value fair equality of life chances, then loyalty grounded in constitutive attachments should be a real possibility for those who wish to stay and improve their neighborhoods within the city limits. Even fractured and impoverished neighborhoods may be sites of formative experiences and shared rituals. Certainly we must not romanticize such spaces and attachments. But given this important caveat, liberals must acknowledge the reasonableness of the desire, on the part of some residents in such places, to work for change in their neighborhoods, to transform their shared spaces from within, exerting meaningful influence over land uses, policing, and schooling - as, for instance, Fung (2001) finds in recent Chicago community initiatives, and as Medoff and Sklar (1994) find in Boston's Dudley Street Neighborhood Initiative, a vigorously inclusive community association that itself holds eminent domain authority over local properties.

But whatever its source, loyalty to place ought not to be expressed through exclusionary practices and institutions that offend the ideal of citizens as free and equal. We are led to this stance not only out of a concern for those left behind, but as a way to ensure that all citizens have available to them feasible opportunities to play an active role in discussions, negotiations, and activities about public

\footnotetext{
${ }^{9}$ The seminal analysis of location and pricing is Hotelling (1929); on spatial competition, see Osborne and Pitchik (1987) and Bester (1989).
} 
services and land uses that affect their life chances. If we seek to enhance the liberal-democratic credentials of metropolitan areas, it will not suffice simply to enhance opportunities for employment and residence across boundaries of class, race, and culture. We must also attend to the processes that generate and sustain these boundaries, by ensuring that marginalized voices have realistic opportunities to alter the spatial status quo.

There are obvious difficulties associated with putting this normative stance into practice, and I cannot do justice here to the complex question of how best to implement the fair worth of political liberty in municipal settings, at least not beyond the argument I have offered that some such implementation seems clearly to be a demand of justice. Again, there have been some promising innovations in local democratic representation that seem to allow many residents to exert meaningful influence over public agendas, especially concerning land uses, school curricula, and community policing. But there are obvious structural factors that hinder any more ambitious efforts to replicate these innovations. There are, for instance, dramatic geographical differences among North American urban areas, in terms of available land, and past commercial land uses that constrain subsequent development. Furthermore, in just those jurisdictions that demand reform as a point of justice, local officials face rigid budget constraints, making it difficult to improve services, even when residents suggest plausible alternative provision and management strategies. And insofar as industrial and other commercial properties in some low-income areas hold the promise of significant tax revenues, officials may be reluctant to exploit these commercial interests for public purposes: in such settings, local administrations tend to privilege business interests that either have a great deal invested in relatively fixed locations within their jurisdictions, or hold the promise of such investment. In addition to generating incentives for corruption within revenue-strapped administrations, this systematic bias also gives these interests greater effective voice in local politics, particularly on issues of land use and taxation. Because of this systematic bias, the costs and benefits associated with many location decisions tend to be assessed in terms of these privileged interests, while the costs borne by other, less advantaged citizens - for instance, lowered property values, disrupted neighborhoods, shifting patterns of employment, and exposure to pollutants - are often discounted (see Harvey 1973, chapter 2; and 1989, chapters 1 and 5; Elkin 1987, chapters 3-5; and Imbroscio 1997, chapters 1-2).

Given these tendencies, what must be prevented, on any effort to achieve fair opportunity for loyalty to place (and the fair equality of political influence that this implies), are uses of local political institutions and informal social mechanisms to control access to, and acceptable uses of, particular spaces in ways that merely sustain location-specific inequalities of resources, and of life chances more generally. Considerations of fairness set limits to jurisdictional autonomy: the requirement of fair influence over land uses and public services does not justify the effective sovereignty of any metropolitan jurisdiction or organization, wealthy or poor. 
Thus the commitment to fair opportunities for loyalty to place puts limits on fragmentation and localism: centralized authority is necessary to provide some essential services, and to coordinate information, monitoring, and enforcement across multiple jurisdictions. ${ }^{10}$ And one such service — vital for realizing a more democratic conception of polycentricity - is ensuring that local autonomy does not sustain objectionable inequalities of life chances. But given such an authority, governments may be able to deploy some degree of fragmentation to liberal and democratic ends, using both mobility and place-based reform initiatives to address injustices and foster responsive government, while ensuring that spatial boundaries between metropolitan jurisdictions are fragile and permeable, thus preventing some residents from using freedom of association and local autonomy to undermine the fair worth of liberties, and fair equality of life chances, for others.

\section{Democratic Hopes: Fairness and Fragile Boundaries}

The polycentric model seems to be implicated with exclusionary practices and rather stark inequalities of wealth and opportunities. Liberals such as Fiss are right to find in mobility a potentially powerful tool for addressing spatial injustice: mobility programs promise to diminish objectionable inequalities by encouraging exit from undesirable locations, and integration into more desirable neighborhoods with better services. But while desirable, mobility alone is insufficient to address the problems for liberal democracy associated with class homogeneity and exclusionary motives in local politics: if our enthusiasm for enhanced mobility is motivated by a desire to achieve not only more responsive government but also a fair equality of life chances, then we should be concerned that mobility-oriented programs threaten to drive a wedge between liberal concerns and democratic hopes.

Given this, we might conclude that political theorists interested in reconciling freedom with fairness should move on, searching instead for a model of urban governance that promises more equitable and inclusive politics than those associated with either the polycentric model or liberal mobility initiatives. The polycentric model seems to reify individual preferences at the expense of fairness and a diverse and inclusive public sphere, instead understanding the public interest simply in terms of efficiency with respect to local public service provision. And although the mobility approach does lead us to challenge urban injustice, it seems to counsel mobility at the expense of place-based reforms, and in doing so threatens to leave in place objectionable strategies of exclusion. Indeed, enhanced mobility undermines the possibility of loyalty to place for the less-affluent, yet allows such loyalty to be expressed in exclusionary ways by the affluent.

\footnotetext{
${ }^{10}$ Relevant here are recent arguments about the possibility of reformed and revitalized regional government in the United States; see Dreier, Mollenkopf, and Swanstrom (2001) and Frug (2002).
} 
We thus have good reasons to be sceptical of the polycentric approach as a liberal and democratic ideal of municipal governance. But the market metaphor underlying this approach has considerable intuitive appeal, and so I ask political theorists to pause and consider an alternative understanding of polycentricity in light of the analysis I have offered here.

The problem with the polycentric approach, as it has generally been understood, is the failure to regulate political practices that maintain economically and culturally homogeneous enclaves within and around central cities. This removes the possibility of conflict that comes with heterogeneity, an outcome that may seem desirable to those with vested interests in high property values and a certain neighborhood "character," but that limits the possibility of constructive political engagement across differences, by citizens understood as free and equal, and acting within institutions that respect them as such.

We should not, then, be persuaded by the claim that freedom of association (particularly regarding locational choices) and jurisdictional autonomy (especially regarding land uses) are unquestionably democratic virtues. Rather, the democratic character of personal liberty and collective autonomy in cities and their regions depend upon how these commitments are balanced, both within and across jurisdictions. I have argued that justice as fairness provides an attractive account of such a balance, and once we take seriously the democratic credentials of this understanding of fairness, we are moved from considerations of mobility and efficiency to adopt further commitments to loyalty and contestation, especially as these play out across urban space.

To be sure, the motivations of citizens matter a great deal to the feasibility of this vision as a guide to policy, but the preferences and motivations of citizens are not exogenous to institutions: a just basic structure will favor aspirations and expectations in accord with an ideal of citizens as free and equal. How might this play out in a city whose boundaries and associated legal architecture take seriously commitments to mobility and loyalty to place, liberty, and fair equality of life chances? Sennett $(1970,147-48 ; 1990,134-37)$ hopes that we can foster and sustain the sort of citizen suited to encounters across difference in urban settings, by avoiding centralized authority structures whenever possible, and ensuring that planning does not seek to shape city spaces according to some antecedent plan of the well-ordered, functional city. Sennett proposes to let historical relations between citizens themselves define the institutional forms characteristic of the spaces they occupy. The spatial forms of metropolitan areas must not reflect only one dominant vision of how and where people ought to live; and more importantly, insofar as some such visions become predominant, they must not constrain the possibilities for alternative ways of living. To avoid such constraints, people must be aware of how their interests and activities affect others and must accept that other values and perspectives may reasonably be brought to bear on their own; there must be ample opportunities for conflict, experimentation, and learning among citizens. 
In many cities we often find citizens rejecting a strong central authority (certainly on matters of land use, although perhaps less so on issues of security). This is certainly in accord with Sennett's proposal. But many affluent citizens simultaneously subscribe to a particular vision of ideal spatial form (i.e., the "character" of their neighborhoods), and actively seek to realize this ideal in their location decisions, and in local political activities. Whether the result of central planning or decentralized politics, the shaping of urban areas into economically homogeneous zones - with limited land uses and considerable autonomy - amounts to an objectionably rigid metropolitan order. We should instead let order emerge as a tentative and fragile stasis in the multifaceted process of social cooperation among the bearers of diverse values and interests, who must find ways to identify and pursue shared ends across cultural, moral, racial, and class differences. Several political theorists share this concern with the democratic potential of urban diversity and disorder (Bickford 2000; Ryan 1998; Young 1990), drawing upon Sennett's vision, but also the influential work of Jacobs (1961). The hope is that we can find, in the density, diversity, and interdependence of modern city life, a soil in which an engaged public and responsive institutions might flourish, without threatening freedom and stifling diversity. Such a vision of metropolitan democracy may well be attainable, or at least reasonably approximated, in something very much like the polycentric city, if we ensure that the search for efficiency and governmental responsiveness through political fragmentation does not undermine the possibility of loyalty to particular places, associated opportunities for effective voice, and fruitful exchanges among citizens across boundaries and especially differences of socioeconomic class.

Again, this suggests a certain fragility to existing boundaries. Boundaries should be meaningful, giving citizens opportunities for real influence over the character of their shared public spaces. But the fruits of such influence are not exempt from calls for public justification, both within and across jurisdictions. And if reasons are not offered, or if they are inconsistent with the ideal of citizens as free and equal, then justice may require that we apply centralized authority across existing boundaries, challenging jurisdictional autonomy over land uses and locational choices, so as to prevent citizens from sorting and sequestering themselves in ways that impose unreasonable burdens on others and generate objectionable differences in the worth of liberty.

We can, given this richer understanding of polycentricity, acknowledge the appeal of spatial sorting and decentralized authority, without becoming mere apologists for fragmentation and localism. We are led instead to an ethically attractive vision of city life, grounded in a spatial and democratic interpretation of justice as fairness.

\section{Acknowledgements}

I thank Joshua Cohen and three anonymous referees for thoughtful suggestions, and Charles Beitz, Susan Bickford, Patrick Deneen, Judith Garber, David Harvey, 
Elinor Ostrom, and Paul Sigmund for helpful conversations. I presented an earlier version of this article at the 2001 meeting of the American Political Science Association in San Francisco, and I have further benefited from contributions by Owen Fiss, Gerald Frug, David Imbroscio, Todd Swanstrom, and Thad Williamson to a roundtable on "Spatial Justice and the City" at the 2002 meeting of the American Political Science Association in Boston.

Manuscript submitted July 11, 2002

Final manuscript received May 13, 2003

\section{References}

Akerloff, George. 1970. "The Market for Lemons." Quarterly Journal of Economics 84 (August): 488-500.

Anderson, Elizabeth S. 1999. "What is the Point of Equality?" Ethics 109 (January): 287-337.

Banerjee, Abhijit V. 1992. "A Simple Model of Herd Behavior.” Quarterly Journal of Economics 107 (August): 797-817.

Bates, Timothy M. 1995. "Why Do Minority Business Development Programs Generate So Little Minority Business Development?" Economic Development Quarterly 9 (February): 3-14.

Bester, Helmut. 1989. "Noncooperative Bargaining and Spatial Competition." Econometrica 57 (January): 97-113.

Bickford, Susan. 2000. "Constructing Inequality: City Spaces and the Architecture of Citizenship." Political Theory 28 (June): 355-76.

Bish, Robert L. 1971. The Public Economy of Metropolitan Areas. Chicago: Markham.

Carens, Joseph R. 1986. "Rights and Duties in an Egalitarian Society." Political Theory 14 (February): 31-49.

Cohen, Gerald A. 2000. If You're an Egalitarian, How Come You're So Rich? Cambridge: Harvard University Press.

Cohen, Joshua. 2001. "Taking People as they Are?" Philosophy and Public Affairs 30 (Fall): 363-86.

Cohen, Joshua. 2003. "For a Democratic Society." In Cambridge Companion to Rawls, ed. Samuel Freeman. Cambridge: Cambridge University Press, pp. 86-138.

Conley, Dalton. 1999. Being Black, Living in the Red: Race, Wealth, and Social Policy in America. Berkeley: University of California Press.

Currie, Janet. 2001. "Early Childhood Education Programs." Journal of Economic Perspectives 15 (Spring): 213-38.

Currie, Janet, and Duncan Thomas. 1995. "Does Head Start Make a Difference?" American Economic Review 85 (June): 341-64.

Daniels, Norman. 2003. "Democratic Equality: Rawls's Complex Egalitarianism." In Cambridge Companion to Rawls, ed. Samuel Freeman. Cambridge: Cambridge University Press, pp. 241-76.

Dreier, Peter, John Mollenkopf, and Todd Swanstrom. 2001. Place Matters: Metropolitics for the Twenty-First Century. Lawrence: University Press of Kansas.

Dworkin, Ronald. 2000. Sovereign Virtue: The Theory and Practice of Equality. Cambridge: Harvard University Press.

Elkin, Stephen L. 1987. City and Regime in the American Republic. Chicago: Chicago University Press.

Epstein, Richard A. 1985. Takings: Private Property and the Power of Eminent Domain. Cambridge: Harvard University Press.

Fiss, Owen. 2003. A Way Out: America's Ghettos and the Legacy of Racism, eds. Joshua Cohen, Jefferson Decker, and Joel Rogers. Princeton: Princeton University Press, pp. 3-43.

Frug, Gerald E. 2002. “Beyond Regional Government.” Harvard Law Review 115 (May): 1764-1836. 
Fung, Archon. 2001. "Accountable Autonomy: Toward Empowered Deliberation in Chicago Schools and Policing." Politics and Society 29 (March): 73-104.

Harvey, David. 1973. Social Justice and the City. Oxford: Blackwell.

Harvey, David. 1989. The Urban Experience. Baltimore: Johns Hopkins University Press.

Hill, Richard Child. 1974. "Separate and Unequal: Governmental Inequality in the Metropolis." American Political Science Review 68 (December): 1557-68.

Hirschman, Albert O. 1970. Exit, Voice, and Loyalty: Responses to Decline in Firms, Organizations, and States. Cambridge: Harvard University Press.

Hotelling, Harold. 1929. "Stability in Competition.” Economic Journal 39 (March): 41-57.

Hoyt, William H., and Stuart S. Rosenthal. 1997. "Household Location and Tiebout: Do Families Sort According to Preferences for Locational Amenities?" Journal of Urban Economics 42 (September): 159-78.

Imbroscio, David L. 1997. Reconstructing Urban Politics: Alternative Economic Development and Urban Regimes. London: Sage.

Jacobs, Jane. 1961. The Death and Life of Great American Cities. New York: Vintage, 1993.

Kollman, Ken, John H. Miller, and Scott E. Page. 1997. "Political Institutions and Sorting in a Tiebout Model.” American Economic Review 87 (December): 977-92.

Lowery, David, and William E. Lyons. 1989. "The Impact of Jurisdictional Boundaries: An Individual-Level Test of the Tiebout Model." Journal of Politics 51(1): 73-97.

Lyons, William E., and David Lowery. 1986. "The Organization of Political Space and Citizen Responses to Dissatisfaction in Urban Communities: an Integrative Model.” Journal of Politics 48(1): 321-46.

McConnell, Shean. 1995. "Rawlsian Planning Theory." In Planning Ethics: A Reader in Planning Theory, Practice and Education, ed. Susan A. Hendler. New Brunswick: Rutgers University Center for Urban Policy Research, pp. 30-48.

Medoff, Peter, and Holly Sklar. 1994. Streets of Hope: The Fall and Rise of an Urban Neighborhood. Boston: South End Press.

Morgan, David R., and Patrie Mareschal. 1999. "Central-City/Suburban Inequality and Metropolitan Political Fragmentation." Urban Affairs Review 34 (March): 578-95.

Nozick, Robert. 1974. Anarchy, State, and Utopia. New York: Basic Books.

Oliver, Melvin L., and Thomas M. Shapiro. 1995. Black Wealth, White Wealth: A New Perspective on Racial Inequality. New York: Routledge.

Oliver, J. Eric. 1999. "The Effects of Metropolitan Economic Segregation on Local Civic Participation." American Journal of Political Science 43(1): 186-212.

Osborne, Martin, and Carolyn Pitchik. 1987. "Equilibrium in Hotelling's Model of Spatial Competition." Econometrica 55 (July): 911-22.

Ostrom, Elinor. 1972. "Metropolitan Reform: Propositions Derived from Two Traditions." Social Science Quarterly 53 (December): 474-93.

Ostrom, Elinor. 1977. “Why Do We Need Multiple Indicators of Public Service Outputs?” 1999. In Polycentricity and Local Public Economies, ed. Michael D. McGinnis. Ann Arbor: University of Michigan Press, pp. 163-75.

Ostrom, Elinor. 1983. "The Social Stratification-Governmental Inequality Thesis Explored." Urban Affairs Quarterly 19 (September): 91-112.

Ostrom, Vincent, Charles M. Tiebout, and Robert Warren. 1961. "The Organization of Government in Metropolitan Areas: A Theoretical Inquiry." American Political Science Review 55(4): 831-42.

Percy, Stephen L., and Brett W. Hawkins. 1992. "Further Tests of Individual-Level Propositions from the Tiebout Model." Journal of Politics 54(4): 1149-57.

Rawls, John. 1999. A Theory of Justice. Revised Edition. Cambridge: Harvard University Press.

Rawls, John. 2001. Justice as Fairness: A Restatement, ed. Erin Kelly. Cambridge: Harvard University Press.

Rubinowitz, Leonard S., and James E. Rosenbaum. 2000. Crossing the Class and Color Lines: From Public Housing to White Suburbia. Chicago: University of Chicago Press. 
Ryan, Alan. 1998. "The City as a Site for Free Association.” In Freedom of Association, ed. Amy Gutmann. Princeton: Princeton University Press, pp. 314-29.

Scharfstein, David S., and Jeremy C. Stein. 1990. "Herd Behavior and Investment." American Economic Review 80 (June): 465-79.

Scheffler, Samuel. 2003. "What is Egalitarianism?" Philosophy and Public Affairs 31 (Spring): 5-39.

Schneider, Mark. 1989. The Competitive City. Pittsburgh: University of Pittsburgh Press.

Sen, Amartya K. 1992. Inequality Reexamined. Cambridge: Harvard University Press.

Sennett, Richard. 1970. The Uses of Disorder: Personal Identity and City Life. New York: Alfred A. Knopf.

Sennett, Richard. 1990. Conscience of the Eye: The Design and Social Life of Cities. New York: Alfred A. Knopf.

Servon, Lisa J., and Timothy Bates. 1998. "Microenterprise as an Exit Route from Poverty: Recommendations for Programs and Policy Makers." Journal of Urban Affairs 20(4): 419-41.

Shklar, Judith N. 1990. The Faces of Injustice. New Haven: Yale University Press.

Taub, Richard P. 1988. Community Capitalism: The South Shore Bank's Strategy for Neighborhood Revitalization. Cambridge: Harvard Business School Press.

Teske, Paul, Mark Schneider, Michael Mintrom, and Samuel Best. 1993. "Establishing the Micro Foundations of a Macro Theory: Information, Movers, and the Competitive Local Market for Public Goods." American Political Science Review 87(3): 702-13.

Tiebout, Charles M. 1956. "A Pure Theory of Local Expenditures." Journal of Political Economy 64 (October): 416-24.

van Parijs, Philippe. 1991. "Why Surfers Should Be Fed: The Liberal Case for an Unconditional Basic Income." Philosophy and Public Affairs 20 (Spring): 101-31.

van Parijs, Philippe. 2003. "Difference Principles." In Cambridge Companion to Rawls, ed. Samuel Freeman. Cambridge: Cambridge University Press, pp. 200-40.

Varian, Hal R. 1974. "Equity, Envy, and Efficiency." Journal of Economic Theory 9 (September): 63-91.

Varian, Hal R. 1975. "Distributive Justice, Welfare Economics, and the Theory of Fairness." Philosophy and Public Affairs 4 (Spring): 223-47.

Young, Iris Marion. 1990. Justice and the Politics of Difference. Princeton: Princeton University Press.

Loren A. King is Visiting Assistant Professor, Department of Political Science, and Postdoctoral Fellow, Watson Institute for International Studies, Brown University, Providence, RI (lking@alum.mit.edu). 